\title{
Anglo-Czech Relations and the Munich Crisis
}

\section{Peter Neville}

Royal Historical Society, London

In 1939 the then British Minister in Czechoslovakia, Basil Newton, had to leave his position in Prague. The reason for this was the destruction of the Czechoslovak unitary state between September 1938 and March 1939. As he departed, he decided to put a Czech machine gun - one of the latest models from the famed Škoda Works - in with the Legation's furniture.

This was a strange paradox, given the fact that for many weeks in 1938 Newton had spent his time trying to persuade the Czechoslovak government not to fight Germany in defence of its sovereignty. In a way, the storage of the Czech machine gun was symbolic of the confusion often apparent in the Anglo-Saxon mind about Czechoslovakia.

\section{Anglo-Czech Connections Before and After the Foundation of Czechoslovakia}

Such ambiguity can be traced all the way back to the foundation of the First Republic by Tomáš Masaryk and Edvard Beneš in 1918-1919. Masaryk's son, Jan, who spent the years from 1925 to 1938 in London as the Czechoslovak Minister to Great Britain, quickly sensed this. Although he later confessed to liking the English, he claimed that they "disliked us intensely. We are a deadweight for them and they curse the day on which we were founded." ${ }^{\prime \prime}$ This despite the fact that his father, the founder of the First Republic, had strong ties with Great Britain. During the First World War Tomáš Masaryk had lived in London, where he taught at King's College, London. He knew Wickham Steed, the Times journalist, and kept up links with Sir George Clerk, later to be British Minister in Prague (1920-1926) at the Foreign Office, and several others.

\footnotetext{
${ }^{1}$ WITTLICH, Filip: 100 let britské ambasády v Praze / 100 Years of the British Embassy in Prague. Prague, WWA photo 2019, p. 33. Quoted in NEVILLE, Peter: Hitler and Appeasement: The British Attempt to Prevent the Second World War. London, Continuum 2006, p. 82.
} 
The problem with the British for the emergent Czechoslovakian state was their ignorance about it. There was a very small group of influential Czechophiles in London, which included the writer and ex-British intelligence officer Robert Bruce Lockhart (the fulcrum for the so called "Lockhart Plot" in Russia in 1918, which was linked to Dora Kaplan's attempt on Lenin's life) who became Commercial Secretary at the Prague Legation in the 1920s and was on friendly terms with both Masaryk and Beneš. ${ }^{2}$ Another admirer of the new Czechoslovakia was the historian Robert William Seton-Watson, who was an expert on Eastern Europe.

British politicians were largely ignorant about Czechoslovakia and its affairs. Indeed, Conservative MPs were known to refer to the state as "Czechoslovenia". Even Sir George Clerk, generally regarded as friendly towards the Czechs, who played tennis with Foreign Minister Beneš and whose wife fostered Czech music in the Thun Palace (the home of the British Legation), suffered from lapses into prejudice, which was characteristic of the British diplomats and their directors in the Foreign Office. ${ }^{3}$

The alleged intolerance of Beneš where revisionist Hungary was concerned caused Clerk to call him an "unconscious opportunist" and Prague a "swollen headed city". ${ }^{4}$ Sympathy for the grievances of the Hungarian minority (the 1919-1920 peace settlement had truncated Hungary, giving much of its territory to Czechoslovakia and Romania) were to be a feature of British diplomacy, which condemned Beneš for chauvinism. Clerk was especially severe on Benešs "meanness of spirit" ${ }^{5}$ where Hungary was concerned, although Hungary understandably had designs on Slovakia which it had ruled for centuries. According to Clerk, Beneš had expressed "a desire to conciliate them but he really in the back of his mind would like to humiliate them on every occasion". ${ }^{6}$

As the biographers of Beneš have pointed out, the strictures of Clerk and his successors, at least one of whom, Sir Joseph Addison, can only be described as a Czechophobe, need to be compared with Clerk's colleagues in Warsaw, Budapest

\footnotetext{
${ }^{2}$ In fact, the originator of the plot to remove Lenin and the Bolsheviks from power was the British secret agent Sidney Reilly, who planned to use Lenin's Latvian Guard to depose him. See LOCKHART, Robert Bruce: Memoirs of a British Agent. London, Putnam 1932, pp. 3-43.

${ }^{3}$ Lady Clerk had some talent as a sculptress and painter but found public occasions difficult as she was afflicted by "a paralysing shyness". See LAWFORD, Valentine: Bound for Diplomacy. London, John Murray 1963, p. 300.

${ }^{4}$ RYCHLÍK, Jan - MARZIK, Thomas D. - BIELIK, Miroslav (eds.): R. W. Seton-Watson and His Relations with the Czechs and Slovaks: Documents 1906-1951. Praha, Ústav T. G. Masaryka 1995, p. 372.

5 ROMSICS, Ignác: Edvard Beneš and the Czechoslovak-Hungarian Border. In: New Hungarian Quarterly, Vol. 32, No. 128 (1992), pp. 94-106, here p. 131.

${ }^{6}$ ZEMAN, Zbyněk - KLIMEK, Antonín: The Life of Edvard Beneš 1884-1948. Oxford, Oxford University Press 1997, p. 60.
} 
and Bucharest who were quite doughty enough in defence of their hosts not to need Clerk's assistance. ${ }^{7}$ Generally though, it must be recognised that Clerk got on well enough with both Masaryk and Beneš, Hungary notwithstanding.

It was the latter in his role as Foreign Minister who had most to do with the Great Powers. Again, the British reaction was decidedly mixed. Lloyd George plainly disliked Beneš, who had caused the British some aggravation over the division of the coalmining areas of Teschen (Těšín), which came back to haunt the Czechs in 1938. He was dismissed by the Prime Minister as "a fussy little man who trots around the world running errands for French Ministers of state". ${ }^{8}$ By contrast, the Foreign Secretary, Lord Curzon, initially called Beneš "a little man for whom we send when we are in trouble. And by jove, he always puts us right." ${ }^{\prime 9}$ This plaudit followed Beneš's introduction to Lloyd George's successor Stanley Baldwin, in the presence of the pro-Czech Bruce Lockhart. This proBeneš feeling did not last long, in part because Beneš, who loved France, moved more into its orbit. Beneš was the founder of the Little Entente (Czechoslovakia, Romania and Yugoslavia) and signed the 1924 Franco-Czech treaty. Czechoslovakia became the lynchpin of France's anti-German security system in Central and Eastern Europe.

This did not go down well in London, where in the early 1920s a slightly absurd Francophobia had taken a grip. In particular the scare associated with that rabid believer in unstoppable bombers and Marshal of the Royal Air Force Sir Hugh Trenchard, who in a bid to secure more funding put it about that France might use its (then) superior air force to blackmail Britain into supporting antiGerman policies. ${ }^{10}$ Trenchard had some success in 1923, the year of Franco-British discord over the occupation of the Ruhr. Lord Curzon believed that "a [French] preponderance of air power and increased strength in submarines [would make it] possible for her to dictate her policy to the whole world". ${ }^{11}$

This wildly inaccurate prediction was, however, symptomatic of a more suspicious attitude to (in British eyes) France's satellite in Prague. The Czechs were too pro-French and British support for them, which was there in 1918-1919, had cooled. When Beneš visited London in 1924 Curzon's greeting was limpid, although Masaryk had told him that he did not want Czech links with France to become too strong. Curzon had moved toward Lloyd George's rather hostile

\footnotetext{
7 ZEMAN, Z. - KLIMEK, A.: The Life of Edvard Beneš 1884-1948. pp. 88-89, 93.

${ }^{8}$ LOCKHART, Robert Bruce: Retreat from Glory. London, Putnam 1934, pp. 70-76.

${ }^{9}$ See footnote no. 7.

${ }_{10}$ DOCKRILL, Michael: British Establishment Perspectives on France, 1936-40. London, Macmillan 1999, p. 5.

${ }^{11}$ Quoted in Ibid., p. 5.
} 
position. Czechoslovakia, he wrote, was "more or less attached to the French chariot wheels". ${ }^{2}$

Back in Prague, Sir George Clerk believed that Czechs were "Germanized Slavs", a somewhat patronizing description which implied that Czech virtues of industry, soberness and especially anti-Bolshevism could be attributed to the influence of the Sudeten German aristocracy. An unhealthy British deference to this aristocracy, a leftover of the old Habsburg empire, appeared right at the start of their relationship with the First Republic. As did a tendency to pounce on Czech defects: Clerk disliked Czech chauvinism and deemed them at times "intolerant and pigheaded". ${ }^{13}$ Though unlike some of his successors he could see that they had their virtues too.

Neither was Czechoslovakia, in the words that became notorious, a faraway country for all Britons. Britain had a considerable economic stake in the new state. It provided half of Czechoslovakia's foreign investment, and was involved in its mining and metallurgy industries. Britain also owned a large part of the Czech textile industry, the glass industry and banking. Most of their vegetable oil was provided by Britain's industrial giant Unilever, while Imperial Chemical Industries (ICI) owned the biggest share of Czech fertilizer plants. The British were also majority shareholders in Explosia the Czech explosive manufacturers. Czechoslovakia was thus well known to Britain's businessmen and bankers. ${ }^{14}$

Clearly though, its Foreign Service remained prejudiced in the handling of Anglo-Czech relations, because of its class-bound attitudes. There could be agreement on some issues however, like the Polish Corridor, bequeathed by Versailles to the Poles to allow them access to the Baltic Sea. Masaryk told the German Foreign Minister, Gustave Stresemann, in 1927, that he did not want to pull Poland's "chestnuts out of the fire"15 should a conflict with Germany break out over the Corridor. He further told the British foreign secretary, Sir John Simon, in 1933 that he would not fight for the Corridor. This would have been music to British ears. Simon's predecessor, Sir Austen Chamberlain, had famously pronounced

12 CORNWALL, Mark: A Fluctuating Barometer: British Diplomatic Views of the Czech-German Relationship in Czechoslovakia, 1918-1938. In: SCHMIDT-HARTMAN, Eva - WINTERS, Stanley B. (eds.): Großbritannien, die USA und die böhmischen Länder 1848-1938. München, Oldenbourg 1991, pp. 313-333.

13 TEICHOVÁ, Alice: An Economic Background to Munich. Cambridge, Cambridge University Press 1974, pp. 47-50.

14 Ibid., p. 50.

15 NEVILLE, Peter: Eduard Beneš and Tomáš Masaryk: Makers of the Modern World. London, Haus 2010, p. 79. 
that the Corridor was not worth "the bones of a British grenadier", ${ }^{16}$ paraphrasing Bismarck.

Thus, two countries allied to France and products of the Versailles system were at loggerheads over both Teschen and the Polish Corridor. There had been further tension with the Poles in 1920-1921, when Czechoslovakia held up supplies at the time of the Russo-Polish War. ${ }^{17}$ Potential friends, both possible victims of a revanchist Germany, thus became enemies with fateful consequences for both.

Sir Austen Chamberlain had further done the two nations little service with the 1925 Treaty of Locarno, of which he was an architect, by excluding them from the terms of the Treaty, and even preventing the Czechs and Poles from being present at the negotiations (an unhealthy echo of Munich). Ominous portents about British Policy thus emerged before the crisis of 1938. Britain would not make a treaty commitment to preserve Czechoslovak borders. Yet, unwilling to contribute meaningfully to Czech security, Britain was still fixated by the Hungarian, German and Polish minorities in the First Republic. Self-determination was a nostrum of Wilsonian League of Nations dogma. Oddly, the British obsession did not explain how the self-determination of Czechs and Slovaks could be preserved while such deference was paid to the other ethnic groupings in the Republic. In the Polish setting, the Labour MP Hugh Dalton called such groups "pet lambs". ${ }^{18}$ In the case of Czechoslovakia they were to prove anything but lamblike however much Masaryk and Beneš tried to appease them.

\section{Relations Between Czechs and Slovaks and British Attitudes Towards Czechoslovakia's Minorities}

A major additional problem was that the Slovaks felt that they too were discriminated against. They saw the Czechs getting the best jobs in the new Republic, although this was the result of the wretched education system imposed by prewar Hungarian rule (the Magyars ruled jointly with the Austrian Germans). Even though Masaryk had a Slovak father, Czechs dominated the Prague government. Beneš allegedly told a visiting British politician that he could not speak Slovak. ${ }^{19}$

\footnotetext{
16 NORTHEDGE, Fredrick Seward: The Troubled Giant Britain Among the Great Powers 1916-1939. London, London School of Economics - Bell 1966, pp. 244-245.

17 DAVIES, Norman: White Eagle, Red Star. London, MacDonald 1972, pp. 174 and 181. The Czechoslovak government is accused of being anti-Polish.

18 PIMLOTT, Benjamin: Hugh Dalton. London, Jonathan Cape 1985, p. 185.

19 BRODERICK, Alan Haughton: Near to Greatness: A Life of Lord Winterton. London, Hutchinson 1965, p. 229.
} 
The economic powerhouse of Czechoslovakia lay in the so-called Historic Provinces of Bohemia and Moravia, not in Slovakia. The ill feeling this generated showed itself in the postwar peacemaking process. Religion also played its part. Rural Slovakia was staunchly Catholic. The Bohemian lands were largely Protestant and more urbanized. The main Slovak political leader was the Catholic Father Andrej Hlinka, who had initially showed some enthusiasm for the unitary state in 1919 claiming that "we are one and one we shall remain. No one and nothing can ever tear us apart."20 This euphoria did not last long, and even Masaryk did not show much support for his father's people. In 1924 he wrote to his daughter Alice about the necessity "to be patient with the Slovaks - they are children or rather spoilt brats" ${ }^{21}$ It could have been Sir Joseph Addison at his worst.

Events may have conspired against Czech-Slovak amity. The most flamboyant and charismatic Slovak leader was Milan Štefánik, who had been designated Minister of War in the fledgling Republican government. The British diplomat Harold Nicolson, who was involved in arranging Czechoslovakia's borders at the Versailles Conference, described Štefánik as "slim... energetic, powerful", yet "a little mad". ${ }^{22}$ Whatever Nicolson's impressions Štefánik was a complete contrast to the meticulous, hardworking Beneš. The two men detested each other, and the Slovak enraged Beneš by accusing him of dishonesty. He was able to get Štefánik sidelined in Paris, and eventually expelled from the Czechoslovak delegation (the conference bored him anyway). Tragically, Štefánik, who had joined the French air force and became a First World War ace (awarded the Legion d'honneur), crashed his aircraft fatally near Bratislava in May 1919.

Although Beneš used flowery language about his late colleague, saying that "he flew over the Allies like a meteor"23 he had been guilty of what Zbyněk Zeman and Antonín Klimek call "slander" against Štefánik. One can only speculate about whether his status in Slovakia, second only to that of Masaryk's, could have been used to bring the two Slav nations together. As it was, Hlinka became the dominant Slovak leader. He arrived in Paris by a roundabout route and told an aide of President Woodrow Wilson that the Slovaks were better off under Hungarian

20 ZEMAN, Zbyněk: The Masaryks: The Making of Czechoslovakia. London, I. B. Tauris 1976, pp. 126-128.

${ }^{21}$ Masaryk Institute and Archives of the Czech Academy of Sciences, Praha [MÚA], fund TGM KOR III, box 749, file 45, Tomáš Garrigue Masaryk to Alice Masaryková, 27 September 1924.

22 NICOLSON, Harold: Peacemaking, 1919. London, Constable 1933, p. 286, entry for 20 March 1919.

${ }^{23}$ ZEMAN, Z. - KLIMEK, A.: The Life of Edvard Beneš 1884-1948, pp. 35-39; MACMILLAN, Margaret: Peacemakers: Six Months That Changed the World. London, John Murray 2004, pp. 252-253; BONSAL, Simon: Suitors and Supplicants: The Little Nations at Versailles. New York, Garden City 1946, pp. 156-164; NEVILLE, P.: Beneš and Masaryk, pp. 27-28 and 54-55. 
rule. The priest thought the Czechs infidels, and gave the American a basic lesson in Slovakian history and geography: "We have lived alongside the Magyars for a thousand years," he said. "All the Slovak rivers flow towards the Hungarian plain, and all our roads lead to Budapest their great city while from Prague we are separated by the barrier of the Carpathians." Hlinka was excluded from the negotiations with the Allied powers in Paris, but he seemed to be suffering from a form of historical amnesia. In 1914 Magyarization in Slovakia was so extreme that of 12,000 civil servants only thirty-five were Slovaks, and for every 700 Slovaks there was one school, against the twenty-five Magyar speakers who were allocated one. This discrimination was one reason why the US city of Pittsburgh had such a huge Slovak population.

There was not a great deal of interest in Whitehall in the rows between the Slav cousins in Czechoslovakia, or the Slovak demand for more autonomy. In 1919 there had been a frisson of interest in March when the extreme Marxist Béla Kun set up a Soviet Republic in Budapest, and then proceeded to invade Hungary's old territory in Slovakia. Nicolson noted that a "communist government had been formed under Béla Kun. Fate of Allied missions uncertain" (Allied diplomats, led by the South African premier Jan Smuts, were on a fact-finding mission). ${ }^{24}$

Czech troops had to be sent to Slovakia to deal with Kun's rag tag army which they were able to do with some ease. An alarming straw in the wind, however, was that these Czech formations were attacked in their rear by Slovak dissidents. Beneš and Masaryk did not know about this worrying development. France supervised the setting up of a pro-Czech borderline.

Meantime the British legation in Prague, prompted by the Foreign Office, continued its exploration of how the Czechs were treating their German, Hungarian and Polish minorities. A curious fixation for a country which at Locarno had washed its hands of any obligation to preserve Czechoslovakia's borders (other than the modest commitment under the League of Nations Covenant).

As usual, there was a degree of inconsistency. Sir George Clerk's wobbling has already been mentioned, but his successor, Sir Ronald Macleay (1926-1930), thought the treatment of the Sudeten Germans fair. In contrast, the historian Robert William Seton-Watson, Masaryk's great friend who was outside diplomatic ambits, told the President that the Slovaks did have genuine grievances. ${ }^{25}$

Macleay veered off instead into a position of condemning Prague's treatment of the Magyars in Slovakia. He also ended up in a position of advocating the despatch of British troops to the Sudetenland where there was Sudeten German rioting (a ploy never suggested by the British in 1938).

\footnotetext{
${ }^{24}$ NICOLSON, H.: Peacemaking, p. 155.

25 Ibid.
} 
A Turn in Anglo-Czech Relations in the 1930s

The worsening of Anglo-Czech relations meant that the British refused to send a delegation to Masaryk's $80^{\text {th }}$ birthday celebration in 1930. This coincided with the appointment of Sir Joseph Addison as Minister to Prague in the same year. Addison proved to be a Slavophobe par excellence. He believed that Czechoslovakia had no right to exist, this belief being underpinned by his essential proGermanism. For Addison, Slavs were a lost cause: “Order, method, punctuality, honesty in dealing with one's fellow human beings are as alien to the Slav character as water to a cat." ${ }^{26}$

When the noted British journalist (and later distinguished historian) Elizabeth Wiskemann met him in 1935, she noted that "he seemed obsessed with the traditional German view that Germans were gentlemen and Czechs were not". ${ }^{27}$ In similar fashion when the young Observer journalist Shiela Grant Duff met Addison in the Thun Palace she asked him if he had any Czech friends; he replied contemptuously "Friends! They eat in their kitchens!"28

While Nevile Henderson (Ambassador to Berlin 1937-1939) was accused of "going native" in pro-German sympathies, Addison had moved in the opposite direction. Six years as a Minister did nothing to alleviate his anti-Czech prejudice. His dispatches were a byword in the Foreign Office for their unsympathetic wording. Yet through all this time Robert Vansittart, the Permanent Under Secretary, often lauded as a great anti-appeaser, did nothing to remove Addison from his post. Indeed, Vansittart showed a level of personal animosity towards Beneš, whom he described as "a blind little bat who has done a lot of flapping in his night". ${ }^{29}$

Underlying the hostility, or in Addison's case pure hatred, towards all things Czech lay a lack of interest in Central and Eastern Europe, which had manifested itself in Britain's Locarno policy. As Bruce Lockhart noted, the view taken in Whitehall was that the small post-war successor states did not matter. They were always at a disadvantage when dealing with the Great Powers. Their diplomats "had to know everything, speak all languages, and know the psychology of his friends and foes alike". ${ }^{30}$ Beneš was able to do this, but it did not make him popular in London, or even in Paris.

\footnotetext{
26 The National Archives, London [hereafter TNA], Foreign Office [hereafter FO] 371/20375, R 5216/32/12, Addison to Foreign Office, 25 August 1936.

27 WISKEMANN, Elizabeth: The Europe I Saw. London, Collins 1968, p. 77.

28 GRANT DUFF, Shiela: The Parting of Ways. London, Peter Owen 1982, p. 96.

29 Documents on British Foreign Policy [hereafter DBFP], $2^{\text {nd }}$ Series, Vol. 18, London, H.M.S.O. 1980,
} No. 185, p. 246, Vansittart minute, 23 February 1937.

30 LOCKHART, R. B.: Retreat from Glory, p. 76. 
Much more typical than Bruce Lockhart's pro-Czech sympathies were judgements made by those Britons who in many instances had never even served in Prague. Thus in 1921, while Sir George Clerk was finding his bearings in Prague, the young diplomat Rennell Rodd, then posted to Sofia, wrote to Harold Nicolson stating his view that "Bulgaria is entirely unimportant, except in so far as peace or war is concerned, in the same way as Czechoslovakia or Switzerland". They did not matter to the British Empire and were "funny little people". ${ }^{31}$ Paul Gore Booth writing in 1936 while on a trip from Vienna to Poland thought the Czechs "totally bourgeois". ${ }^{2}$

This was Addison land. In 1933 he blasted the Czech as "not celebrated either for his (or her) beauty or his (or her) charm". ${ }^{33}$ By this time, the situation in the Prague Legation had been made worse by the appointment of Robert H. Hadow as Counsellor. He was a chip off the Addison bloc, and his dispatches to the Foreign Office were equally unfriendly towards the Czechs. Hadow and Addison both believed that Czechoslovakia had no right to exist and was unstable (a view that came to be shared by Basil Newton, the Minister from 1937 to 1939).

Both had served in Berlin and were biased in favour of the ethnic German minority. Britain's job, both men believed, was to apply pressure in Prague where the Sudetenland was concerned, and force Beneš (Foreign Minister until 1935 and then President until 1938) to make concessions to the Sudeten Germans. If Britain failed, declared Hadow in melodramatic terms, there might be "a second thirty years war". ${ }^{34}$

The weight of British diplomatic opinion can seem puerile in tone and trivial (though the very recent withdrawal of a British Ambassador in Washington for being blunt about the Trump presidency underlines the tendency of diplomats to be scathing about the governments to which they are posted on occasion). Its importance lies in the fact that an anti-Czech culture had persisted in the Foreign Office and Diplomatic Service since the post-war settlement of 1919-1920. While wanting to allocate a right to meddle where minority rights were concerned, the British also disclaimed responsibility for Czechoslovakia's survival

31 Bodleian Library, Oxford University, United Kingdom, $2^{\text {nd }}$ Lord Rennell of Rodd Papers, Frances Rodd to Harold Nicolson, 25 June 1921.

32 Ibid., Gore Booth MS, Eng, c.4547, Diary fragment of the trip from Vienna to Poland, 15 September 1936.

33 Churchill College Archive, Cambridge University, United Kingdom, Bland Papers, BLND 9/13, Addison to Bland, 8 August 1933.

$34 D B F P, 2^{\text {nd }}$ Series, Vol. 18, No. 185, pp. 246-248, Hadow to Foreign Office, 16 February 1937. See also MITCHIE, Lindsay: Portrait of an Appeaser: Robert Hadow, First Secretary in the British Foreign Office 1931-1939. London, Praeger 1996. 
at Locarno (the French were to be little better, despite their 1924 and 1925 treaties with Prague).

It would be wrong to imagine though that the Czechs were singled out for hostility. Even Sir Horace Rumbold (Ambassador to Berlin 1928-1933), the hero of the anti-appeasement narrative in Britain, was afflicted by ethnic and religious prejudice. When sent to Berlin he was appalled by the number of Jews there, and when previously posted to Warsaw he thought the Poles "thoroughly corrupt" so that he wondered if "they would make anything of their country". The French were written off as "cads and apes". ${ }^{35}$ The conviction of British superiority and the wretched folly of foreigners, had a firm grip on the diplomatic psyche.

Questions have been raised, however, about whether Edvard Beneš presented himself to best advantage to British diplomats in Prague. In 1935 he paid a visit to Moscow and met Stalin. On his return, and most oddly, he chose to brief Sir Joseph Addison, who was notoriously anti-communist. The briefing lasted one hour and forty minutes and Beneš praised the Soviet Union and Stalin in glowing terms. Addison even being told that Beneš's wife had found no shortages in the shops, a palpable inaccuracy.

What was Beneš trying to achieve here? It would surely have been wiser for Jan Masaryk, well liked as Czech Minister in London, to brief the Foreign Office about his boss's experience in the Soviet Union, while perhaps putting a dampener on Beneš's exaggerations, and inaccuracies. Igor Lukeš has also underlined his tendency to lecture at great length "experienced foreign diplomats who soon resented being treated as students of international affairs". ${ }^{36}$

The Czechophobe Addison made great play with Beneš's supposed role as a Soviet stooge in his report to the Foreign Office about the interview. The error by Beneš could also be played upon by those such as Orme Sargent, Vansittart's deputy, who was already violently anti-Soviet and thought Czechoslovakia to be "practically (...) the aircraft mothership" of Moscow. ${ }^{37}$

35 GILBERT, Martin: Sir Horace Rumbold. London, Heinemann 1973, pp. 187 and 319.

${ }^{36}$ Quoted by HANAK, Harry: The Visit of the Czechoslovak Foreign Minister Dr Edvard Beneš to Moscow in 1935 as seen by the British Minister in Prague Sir Joseph Addison. In: Slavonic and East European Studies, Vol. 54, No. 4 (October 1976), pp. 388-391; LUKES, Igor: Czechoslovakia Between Stalin and Hitler: The Diplomacy of Edvard Beneš in the 1930s. Oxford, Oxford University Press 1996, p. 56.

${ }^{37}$ DBFP, $2^{\text {nd }}$ series, Vol. 18, No. 160, pp. 208-212, Sargent's memorandum on Czech-German talks, 9 February 1937. Michael Carley gives a detailed analysis of Sargent's Soviet-phobia in: CARLEY, Michael Jabara: A Fearful Concatenation of Circumstances: The Anglo-German rapprochement 1934-1936. In: Contemporary European History, Vol. 5, No. 1 (1996), pp. 29-69. Sir Joseph Addison's violent report on the Beneš interview can be found in TNA, FO 371/19461, N 3240, 27 June 1935. 
1935 was also the year when Czechoslovakia signed a mutual defence treaty with the USSR, which at Czech insistence included a clause ensuring that it would not come into effect unless France honoured her parallel treaty first. The CzechSoviet treaty was detested in Whitehall, but in reality changed little. Although Great Britain did not have a military agreement with France (the source of much annoyance in Paris), there was no doubt that given a choice between London and Moscow, France would always opt for the former.

Conversely, Beneš had insisted on the change in the Soviet treaty being dependent on French action. In his eyes France was always the key Czech ally, just as Britain was for the French. This was to create an imbroglio in September 1938 when a situation arose where France refused to honour its 1935 commitment, and the Soviet Union was left the choice of acting unilaterally. The evidence does not suggest that Stalin ever intended to support the Czechs, who were in any case rather suspicious of Soviet intentions. British dislike of the Czech-Soviet treaty was used by their government to put pressure on Prague, as a price of British support for an independent Czechoslovakia.

The shadow of Munich can thus be seen operating in reverse in the early 1930s and beyond. The security supposedly created by Beneš in 1935 would collapse, and the constant British fixation with Czechoslovakia's "pet lambs" came into play with the Sudeten problem. Their dislike of the Franco-Czech treaty of 1935 was at the core of British diplomacy, and its involvement in the Munich crisis essentially a means of preventing France, whose sovereignty they felt bound to protect, alongside that of Belgium, from honouring its commitment to Czechoslovakia. The French were fully aware of this and followed the British lead in 1938.

In Prague, the disappearance of Addison as British Minister saw a slight alleviation in anti-Czechism. Sir Charles Bentinck (1936-1937) had little time to make any real impact, although he seemed to think that the Sudeten problem was solvable by negotiation. This brought down on his head the famous caustic wit of Sir Eric Phipps (British Ambassador in Berlin 1933-1937). He rejected the idea of Britain "butting in" to the question of Sudeten autonomy, although he did not feel that Germany was in any position to have designs on Czechoslovakia as it was not ready. This observation can be found in the diary of Anthony Eden's private secretary, Oliver Harvey, who on 27 February 1937 reported a meeting at the Foreign Office attended by Foreign Secretary Eden, Vansittart, Viscount Cranborne (Eden's deputy), Orme Sargent, Alexander Cadogan and Harvey. Harvey reported that Jan Masaryk was having talks with Joachim von Ribbentrop, the German Ambassador in London (a surprising scenario). Beneš should be told, the meeting decided, that Britain wanted his country to have good relations with all of its neighbours, but the British "should not take the responsibility 
of urging agreement as Beneš might interpret this as encouragement to desert from France and Russia, or as committing Great Britain to stand by him if negotiations failed". ${ }^{38}$

Oliver Harvey's master, Eden, was reasonably sympathetic to the Czechs, reacting to one of Addison's diatribes by observing that "whatever the faults of the Czechs, they are tough, and they have a good fighting record". Quite justly, Eden reproved Addison for not understanding the European dimensions of the Sudeten problem. ${ }^{39} \mathrm{He}$ also reproved Addison's ally Hadow, telling him on 23 February that the evidence available to the Foreign Office "tended to show that the German government's policy is directed towards the disintegration of Czechoslovakia". ${ }^{40}$

Once this was established the question was, given the Locarno principle of non-engagement in Central and Eastern Europe, what Britain was going to do about it.

Writing in his memoirs many years later Eden stated that there was no sufficient motive for intervention or arbitration, because the Czechs treated their minorities better than most countries. ${ }^{41}$ Some of his Foreign Office colleagues did not accept this reality, like the denizens of the Prague Legation.

Meanwhile the British policy was one of detachment. There were those who criticised the Czechs in the Foreign Office and Diplomatic Service, but the official line under Eden (until February 1938) was that Prague should be encouraged to negotiate with Sudeten German representatives. Concessions by Beneš on issues like the Czech police presence in the Sudetenland and the German language, might head off any overt interference by Adolf Hitler. This proved to be a basic misreading of the situation in Czechoslovakia in 1937-1938. There could be bilateral Czech-German talks about the Sudetenland, but they could never succeed because Hitler did not want them to.

\footnotetext{
38 HARVEY, John (ed.): The Diplomatic Diaries of Oliver Harvey 1937-1940. London, Collins 1970, entry for 27 February 1937, p. 18. Bentinck was a count of the Holy Roman Empire, an honour bestowed upon his family by the Habsburg Emperor Charles VI, which may have pleased the Sudeten German aristocracy, but was not likely to appeal to Beneš and his government.

39 EARL OF AVON: Facing the Dictators. London, Cassell 1962, pp. 502-503. See also: TNA, FO 371/20375, R 5216/32/1, Eden minute 15 September 1936.

${ }^{40} D B F P, 2^{\text {nd }}$ Series, Vol. 18, No. 200, pp. 278-279, Eden to Hadow, 23 February 1937. Why the Foreign Office kept a man in post who began a dispatch with the line "there is no such thing as Czechoslovakia" remains a mystery. Quoted in HENDERSON, Sir Nevile: Water Under the Bridges. London, John Murray 1945, p. 219.
}

${ }^{41}$ EARL OF AVON: Facing the Dictators, p. 503. 
The Appointment of Basil Newton, the New British Minister in Prague, 1937

A key event in the lead up to Munich, and the sequestration of the Sudetenland was the appointment of Basil Newton as British Minister in Prague, who took up his post on 3 March 1937. Newton had formerly been the Counsellor in the Berlin embassy, and thus knew all about the thuggery and brute force associated with National Socialism.

Given what happened to Czechoslovakia and his role in its demise, it is relevant to note here what Bruce Lockhart, a great friend of Czechoslovakia, thought about Newton, with whom he had served briefly (Lockhart was to be "British Representative" attached to the Czech government-in-exile in 1940).

Newton, according to Lockhart was "shrewd in judgement and tactful in manner, he possesses an almost judicial impartiality, a quality valuable in a diplomat, essential in a country like Czechoslovakia, and unfortunately not possessed by all previous British Ministers [a possible sideswipe at Addison]. Basil Newton, I felt, was a sound man for a delicate and most difficult situation."

President Beneš would not have agreed with this assessment. He called Newton a "thick headed ignoramus". Yet Bruce Lockhart's testimony cannot be ignored. He met Newton again, on a Vansittart-inspired lecture tour of Czechoslovakia, and commented on how the Prague Legation was "exotically furnished with the Chinese treasures Newton had brought back from Peking after his posting there". ${ }^{42}$ Plainly there was more to the man than Beneš was ready to concede.

Newton was not thought to be one of these diplomats who went "native" like Henderson while in post. Although Lockhart, albeit on a brief visit, thought that Newton "knew both the Czech and German point of view" ${ }^{43}$ Yet his subsequent performance in Prague cannot be described as impartial. It has pertinently been observed that the damage was probably done before he even arrived there. He had read and accepted much of what Addison had written about Czechoslovakia's German minority. As Minister he was placed in an environment where most of his colleagues in London and Prague had already convinced themselves that the Czechs were morally in the wrong. ${ }^{44}$ That Newton did not prove to be impartial cannot therefore be described as a surprise.

\footnotetext{
42 LOCKHART, Robert Bruce: Guns and Butter? London, Putnam 1938, pp. 263-264.

43 CORNWALL, Mark: The Rise and Fall of "A Special Relationship": Britain and Czechoslovakia, 1930-1948. In: BRIVATI, Brian - JONES, Harriet (eds.): What Difference Did the War Make? Leicester, Leicester University Press 1993, pp. 130-150 and 138.

$44 D B F P, 2^{\text {nd }}$ Series, Vol. 18, No. 160, pp. 208-212, Sargent's memorandum on Czech-German talks, 9 February 1937, Vansittart minute, 9 February 37. See footnote no. 37.
} 
The directions he was given by the Foreign Office hardly helped. Orme Sargent believed that Prague was providing aid and comfort to the Comintern (the international agency of the Soviet Communist Party), and thought that in taking up his new post Newton should investigate this (Vansittart minuted "I agree"). ${ }^{45}$ In a sense then Newton's card was already marked. ${ }^{46}$ Sargent suffered from the curious delusion that the problem was Czechoslovakia's adherence to its 1935 pact with the Soviet Union, which had sparked off an anti-Czech campaign in the German press. ${ }^{47}$ Hitler of course, could be expected to object to both the FrancoCzech and Czech-Soviet pacts as part of German paranoia about encirclement.

Newton's predecessor Addison had put forward the idea that the introduction of a Swiss-style cantonal system was impossible because up to 90 per cent of Sudeten Germans were Nazis, who wanted union with the Reich (Beneš believed that 25 per cent of Sudetens opposed a union). Newton ran with the idea of a cantonal system based on his belief that the Czech state was unviable because of the minority problem. This belief can be traced in his telegrams throughout the Czech crisis between March and September 1938. Newton thought that Czechoslovakia should be given neutral Swiss status, which would make it into "a kind of sanctuary or reserved area immunized against aggression" ${ }^{48}$ The attempt to secure French or Soviet help "against aggression" was not to be allowed, however.

The unhealthy influence of Addison was evident in Newton's comment to Foreign Secretary Lord Halifax that the Czechs "suffered from temperamental obstinacy which prevented them from compromising and was liable to make their country more untenable every day". It was of course Halifax and Chamberlain who made policy, but traces of Newton's thinking can easily be found in the Foreign Secretary's speeches in the House of Lords (Richard Austen Butler represented the Foreign Office in the Commons) and elsewhere.

\footnotetext{
45 For additional detail on the circumstances surrounding Newton's appointment see: NEVILLE, Peter: Nevile Henderson and Basil Newton: Two British Envoys in the Czech Crisis 1938. In: Diplomacy and Statecraft, Vol. 10, No. $2 \& 3$ (July/November 1999), pp. 258-275. See also: VYŠNÝ, Paul: The Runciman Mission to Czechoslovakia 1938: Prelude to Munich. London, Palgrave 2003, pp. 12 and 14.

${ }^{46}$ NEVILLE, P.: Nevile Henderson and Basil Newton, p. 260.

47 DBFP, $3^{\text {rd }}$ Series, Vol. 1, London, H.M.S.O. 1949, No. 140, pp. 151-154, Newton to Halifax, 12 April 1938.

48 Ibid., No. 140. Shiela Grant Duff quotes Newton talking about the Czechs as "an obstinate race with whom fear may more easily breed hatred than readiness to yield". See GRANT DUFF, S.: The Parting of Ways, p. 159.
} 


\section{British Military Strategies}

Diplomacy was one matter, but in the days that followed Hitler's annexation of Austria in March 1938 military factors became more and more dominant as the British documents show. The most immediate one was that the absorption of Austria into the Reich unmasked part of the Czech border. Facing Germany, the Czechs had sophisticated fortifications perhaps as good as the Maginot Line, but after the Anschluss they were involved in a desperate struggle to improvise adequate defences along the old Czech-Austrian border.

This change in the military status quo was pounced upon by the British Chiefs of Staff in a notorious statement on 21 March 1938, barely a week after the $A n$ schluss. Czechoslovakia, they opined, could only be preserved by "the defeat of Germany and as the outcome of a profound struggle (...) [and] Italy and Japan would seize the opportunity to further their ends and in consequence the problem we have to envisage is not that of a European War but of a World War. This could last for many years." ${ }^{\prime 9}$

Neville Chamberlain was equally brutal about Czechoslovakia's chances in a letter to his sister Ida on 24 March. Chamberlain pointed out that "the Austrian frontier is practically open, the great Škoda Munitions Works are within easy bombing distance of German aerodromes; the railways all pass through German territory. Russia is a hundred miles away. Therefore we could not help Czechoslovakia." ${ }^{50}$ Another line of British argument was thus provided. Not only was the moral case against the Czechs conclusive (Versailles endorsed Woodrow Wilson's self-determination dogma), but Britain was in no military position to help them either. Britain could not, and would not, help Czechoslovakia but it would hide behind a complex formula. Germany was to be kept in the dark by a strategy of suggesting that, as France might intervene to honour its commitment (though the Foreign Office knew all about French unwillingness to do so), Britain might be obliged in that situation to assist France against Germany. It was a high-risk strategy where Berlin was to be bluffed, and moving away from the Eden line, Prague to be pressured by Newton to make concessions to the Sudetens, or risk obliteration.

The interesting point about Chamberlain's policy towards Czechoslovakia was that one obvious option was rejected. At no point did Chamberlain, according to the documentary evidence, seriously consider a policy of complete disengagement

\footnotetext{
49 TNA, Cabinet Papers [CAB] 26/627, Chiefs of Staff (COS) 698, Military implications of German aggression against Czechoslovakia, 21 March 1938.

50 University of Birmingham Archive, United Kingdom, Chamberlain Papers, Neville to Ida Chamberlain, 24 March 1938.
} 
leaving it to France, the Soviet Union and Czechoslovakia to deal with the German attempt to annex the Sudetenland.

Instead, increasingly heavy pressure was applied to Beneš and his government by Newton and his French colleague Léopold Victor de Lacroix (although the latter was far more sympathetic to the Czechs than his British counterpart). ${ }^{51}$ Newton's message to the Czech Foreign Minister Kamil Krofta on 9 May was typical of Anglo-French blackmail. It would, said Newton, be "very difficult to defend Czechoslovakia" and if there was to be a wider conflict it "would still have to be decided whether the Czechoslovak state could be re-established in its present form". Newton also managed to refer to the state of British public opinion which would not, he claimed, gamble on a war in the Sudetenland. He needed to stress this, Newton told Krofta because "it is not uncommon for Czechs to take the line that Germany would never venture on war if she knew in advance that France, Great Britain and Russia would come to the aid of Czechoslovakia". ${ }^{52}$ This twisted bit of logic effectively condemned the Czechs for having hope of succour.

Underlying all the assumptions of Chamberlain, Halifax and Newton was the belief that the Czechoslovak Republic was indefensible. This assumption has been challenged in a very recent study, The Bell of Treason by P. E. Caquet. In his view "the Polish defeat of 1939 retrospectively distorts estimates of the Czechoslovaks chances". The Poles, he writes, "were slaughtered in that open country, while the Czechs would have mountain borders to defend". Caquet's analysis, though, ignores the potential impact of German airpower, save to say that their dive bombers would not be able to damage the concrete Czech casemates. ${ }^{53} \mathrm{In}$ contrast, the Czech historian Milan Hauner is cold eyed in a brutally realistic assessment, whereby Germany had "an overwhelming superiority in the air". ${ }^{54}$ Caquet is optimistic about the roles that the Czech allies France and the Soviet Union could play. Hauner is almost certainly right to say that the French strategists would not, in the event of war abandon their determination to "sit out the next war safely behind the Maginot Line". ${ }^{55}$

This was exactly what happened a year later when General Maurice Gamelin launched a tiny "squib" offensive in the Saarland, leaving the Poles to their

\footnotetext{
${ }^{51}$ DBFP, $3^{\text {rd }}$ Series, Vol. 1, No. 195, pp. 265-271, Newton to Halifax, 9 May 1938.

${ }^{52}$ Quoted in: WEINBERG, Gerhard: The Foreign Policy of Hitler's Germany Starting World War Two. Chicago, Chicago University Press 1980.

${ }^{53}$ CAQUET, P. E.: The Bell of Treason: The 1938 Munich Agreement in Czechoslovakia. London, Profile Books 2019, p. 144.

${ }^{54}$ HAUNER, Milan: The Sudeten Crisis of 1938: Beneš and Munich. In: McDONOUGH, Frank (ed.): The Origins of the Second World War, London, Continuum 2011, pp. 360-373, here p. 360.

${ }^{55}$ Ibid., p. 361.
} 
fate. Hauner also makes an admission that British counter-revisionist historians have (in my experience) never been willing to concede about the Munich Crisis. That is that "the unreliability of ethnic minorities [Germans, Hungarians and Poles] would have been a factor in 1938, even if not a decisive one" ${ }^{56}$ It would have been reasonable for British strategists to take this element into consideration with regard to Czechoslovakia. It was of course part of the Addison/Newton line in the sense that they believed Czechoslovakia to be a mongrel state. Nonetheless an important caveat has to be entered here. No Ambassador or Minister directed British foreign policy. Oliver Harvey, a persistent critic of Nevile Henderson in Berlin for alleged pro-Germanism wrote in 1939 that "no Ambassador is going to swing Hitler or German opinion. German policy is governed by British policy in London" ${ }^{57}$ Likewise Czechoslovak policy was formulated in London, whatever Newton said in his telegrams, and his masters had other sources of information.

Reverting again to the military issue, it has to be recognised that the French strategy was an ultra-defensive one. The French Commander-in-Chief, Maurice Gamelin, had according to one analyst "disassociated himself from the fate of Czechoslovakia in March 1938 at the time of the Anschluss". This followed a lengthy period, going back to the early 1930s, when Gamelin's policy was to create a situation where France's Eastern allies did the fighting, while it sheltered behind the Maginot Line (albeit weakened by Belgium's decision to denounce the 1920 France-Belgian military agreement). ${ }^{58}$

British strategy was also defensive, with an army designed largely for colonial service. It was also immobile: the famous British tank commander Major General JFC Fuller quit the War Office in disgust because "its officials were uninterested in anything that did not shit and eat hay". ${ }^{59}$ Neville Chamberlain did make the effort to read the great military theorist Basil Liddell Hart, whose nostrum was that an attacking force needed a three-to-one superiority in numbers to make a successful offensive. This played into an assumption that Britain would not need a seventeen-division army (as demanded by Vansittart and his supporters), as France's defensive strength could see off the Germans. The static French strategy with its outdated tank doctrine provided for none of the mobile forces

\footnotetext{
${ }^{56}$ NEVILLE, P.: Hitler and Appeasement, pp. 125-126.

${ }^{57}$ HARVEY, J. (ed.): The Diplomatic Diaries of Oliver Harvey 1937-1940, pp. 292-294, entry for 27 May 1939. ${ }^{58}$ JORDAN, Nicole: The Cut Price War on the Peripheries: The French General Staff, the Rhineland and Czechoslovakia. In: BOYCE, Robert - ROBERTSON, Esmonde (eds.): Paths of War: New Essays on the Origins of the Second World War. London, Macmillan 1989, pp. 128-166.

59 RANSOM, Edward: British Defence Policy and Appeasement Between the Wars 1919-1939. London, Historical Association 1993, pp. 9-11.
} 
needed to break through German defences.$^{60}$ Assistance to Czechoslovakia required a mobility that was invisible in Anglo-French military doctrine (and only two British divisions were available at the time of Munich).

The USSR and Its Role at the Time of the Munich Agreement

There were intangibles at the time of Munich. One was what would the USSR linked to Czechoslovakia by the 1935 pact do?

Successive British governments were hopelessly prejudiced against the Soviet Union, yet their suspicions were not entirely unreasonable. Soviet aid to Prague had to involve troop movements across Poland and/or Romania. The British detested the Czech-Soviet treaty as has been seen, but Chamberlain and Halifax were also bombarded with pessimistic reports about Soviet potential from their military attaché in Moscow, Colonel Roy C. Firebrace (it was well known that Stalin had purged some 40 per cent of the Red Army, including five Red Army Marshals and the Commander-in-Chief). There were also suspicions in the Beneš government about Soviet intentions, as will be seen, despite the President's euphoric description of his 1935 visit to the Soviet Union, and his interview with Joseph Stalin.

The defence priorities of the Chamberlain government had been spelt out by the Minister for Co-ordination of Defence, Sir Thomas Inskip, in a paper presented to the Cabinet in December 1937. This listed Britain's strategic priorities as: (i) the protection of the home country against air attack, (ii) the defence of British trade routes, (iii) the defence of Britain's overseas territories, (iv) co-operation in the defence of any wartime allies. ${ }^{61}$

On the face of it, Czechoslovakia did not fit into the fourth category. Unlike France, Britain did not have a military obligation towards Prague, and counterarguments put forward in the Cabinet ran into the arguments that Chamberlain had put to his sister in March 1938. The Soviet factor was dismissed by British Ministers (with the possible exception of Sir Samuel Hoare, the Home Secretary) not only because of the geographical factors put forward by Chamberlain and his Chiefs of Staff, but also because of the damage sustained by the Red Army in the purges of 1937-1938. A pioneering study by Hugh Ragsdale in 2004 suggested that the Romanians would have been prepared to allow passage of the

60 BELL, Philip: The Origins of the Second World War in Europe. London - New York, Longman 1986, pp. 171-178; NEVILLE, P.: Hitler and Appeasement, p. 125.

61 Quoted in: PEDEN, G. C.: British Rearmament and the Treasury 1932-1939. Edinburgh, Edinburgh University Press 1979, pp. 134-135. 
Red Army through their country but had little to say about Polish antipathy to the Soviet Union which had deep historical roots. Indeed, he had to concede that even Romania was severely handicapped because no "rail line of any kind provided a direct communication between the Soviet Ukraine and Czechoslovakia, and all lines in the area were single track" ${ }^{62}$

Ragsdale's argument that five Soviet armies were stationed along the PolishSoviet border in September 1938 might seem impressive, but they would have had to fight their way in, and the events of 1920 warned that it might have been a bloody affair (the Red Army reached the gates of Warsaw but was then repulsed by the Poles who invaded Ukraine). Other historians, like Igor Lukeš, have remained sceptical about Soviet intentions. He bases such scepticism on Benešs own assessment of Soviet behaviour at the time of Munich. His belief was that Stalin had behaved "deceitfully" and that "the USSR did not want to help us". Beneš pointed to the fact that the Soviet Union had never replied to his request for unilateral assistance, until 72 hours after the Munich Agreement was signed. Beneš himself had anti-communist tendencies, contrary to the prejudice of people like Orme Sargent. According to Ernst Eisenlohr, the German Minister in Prague (whose relative probity was unusual for a German diplomat in the Nazi era), Beneš told him in a lengthy interview in February 1936 that he was "determined to fight communism in Czechoslovakia".

British Appeasement Policies, 1937-1938

The same diplomat was the recipient of an interesting comment by Beneš in 1937. The British, he told Eisenlohr, "were too far away to understand things". This throwaway remark seems to provide cover for Chamberlain's notorious reference to Czechoslovakia as "a faraway country" of whose people Britons "knew nothing" in his pre-Munich BBC broadcast. ${ }^{63}$ When a Daily Express headline asked "Where is Prague?" it reflected ignorance on the part of the British population, as well as a fervent desire to avoid War.

It was certainly true in the wider European context that the British did not understand things in the weeks and months leading to Munich. The mediator,

\footnotetext{
62 RAGSDALE, Hugh: The Soviets, the Munich Crisis and the Coming of the Second World War. Cambridge, Cambridge University Press 2004, pp. 158-167.

63 Documents on German Foreign Policy [hereafter DGFP], Series C, Vol. 4, London, H.M.S.O. 1962, No. 580, pp. 1177-1183, Eisenlohr to Wilhelmstrasse, 23 February 1936; DGFP, Series D, Vol. 1, Washington, Government Printing Office 1949, No. 93, Eisenlohr to Wilhelmstrasse, 21 January 1937; FEILING, Keith: Neville Chamberlain. London, Macmillan 1946, p. 372.
} 
Lord Runciman, who was sent to Czechoslovakia in August 1938, affronted Czech sensitivities by spending five of six weekends in the country with Sudeten German aristocrats, and produced a report which recognised Czech rights but somehow accused them of being unjust to the Sudetens. Absurdly, Runciman concluded his report by saying that the Czechoslovaks should "remodel" their foreign relations so as to give reassurance to their neighbours "that they would in no circumstances attack them". ${ }^{64}$

It is surprising, to say the least that a man as normally astute as Vansittart was taken in so easily. As late as 16 May "Van" as everyone called him, was minuting that Konrad Henlein, Leader of the Sudetenland German Party, "had no instructions from Berlin". ${ }^{65}$ This was two days before rumours about a forthcoming German attack on Czechoslovakia appeared on 21 May (the so-called "May Scare"). For once Hitler was innocent, but days later he told his generals of his determination to "smash Czechoslovakia". ${ }^{6}$

In fact, Vansittart remained convinced that the Germans were behind the scare, which was genuine. This was not the view taken in Whitehall, where the British government believed (prompted by Henderson) that the embarrassment of Hitler was dangerous and could push him over the "borderline" into insanity. ${ }^{67}$ Such provocations were to be avoided, although following crowing in the British press the original line was that Britain, France, and the USSR had deterred Hitler. Two unlikely allies could be found against this theory: Henderson, and the fiery but unreliable first Lord of the Admiralty, Alfred Duff Cooper, who wrote in his diary on 22 May that everyone here believed that Hitler's alleged setback was entirely due to the firmness of the British Government. This, Cooper said,

${ }^{64}$ VYŠNÝ, P.: The Runciman Mission to Czechoslovakia 1938, p. 30, Appendix I, The Runciman Report, p. 348.

${ }^{65} D B F P, 3^{\text {rd }}$ Series, Vol. I, Appendix 2, pp. 630-633. As Igor Lukeš points out, Vansittart's friendly links with Henlein were an embarrassment to the Foreign Office. See LUKES, I.: Czechoslovakia Between Stalin and Hitler, p. 89, footnote 31. Lukeš credits Bruegel for noticing the omission of the following sentence from Appendix 2 of the relevant $D B F P$ Volume. It read: [Vansittart speaking] "I have been on very friendly terms with Herr Henlein for some six years past, and have seen him frequently during his visits to London." See BRUEGEL, Johann Wolfgang: Czechoslovakia Before Munich. Cambridge, Cambridge University Press 1973, p. 21. A defence of sorts is put up by Vansittart's biographer Norman Rose, who has to concede that "Henlein certainly deceived Van". See: ROSE, Norman: Vansittart: Portrait of a Diplomat. London, Heinemann 1978, p. 223.

${ }_{66}$ The origins of the "scare" remain controversial. See for example LUKES, Igor: The Czechoslovak Partial Mobilisation in May 1938: A Mystery (almost) Solved. In: Journal of Contemporary History, Vol. 31, No. 4 (1996), pp. 699-720.

${ }^{67}$ NEVILLE, P.: Hitler and Appeasement, pp. 75-78. 
was "a complete misapprehension". ${ }^{68}$ It might have seemed good news in Prague too. Beneš wrote later that in "all truly diplomatic circles in Europe there existed the conviction that our resolute action had saved the peace". ${ }^{69}$

Yet two of his biographers have accused him of a tactical blunder that May weekend, which meant that later appeals for help were discounted by the Anglo-French. The Soviet intelligence link saw Stalin passing on false information to Beneš (in 1937 he had been hoodwinked by an innocent Beneš into accepting bogus German information about the Red Army Commander-in-Chief Marshal Mikhail N. Tukhachevsky, who was then executed as a traitor). ${ }^{70}$ In May 1938 the mobilisation of thousands of extra Czech troops did allow Prague to stabilise the situation in the Sudetenland, where Henlein and his acolytes were stirring up trouble.

Beneš of course knew that Henlein was a Nazi stooge, and he was unenthusiastic about accepting an elderly out of touch ex-British cabinet minister (effectively retired by Chamberlain) - Lord Runciman - as a mediator. His problem was that France in the words of a noted French historian was following "the English governess" in relation to policy over Czechoslovakia. ${ }^{71}$ Prime Minister Édouard Daladier was only appraised of the plan to send Runciman to Czechoslovakia after the event. If France chose to follow Chamberlain's lead, Beneš could not resist having Runciman foisted on him.

Likewise Plan Z, whereby Chamberlain descended upon Germany in midSeptember, was kept secret from both Beneš and the French. It is possible to see Chamberlain's visits to Berchtesgaden, Godesberg and Munich as an early form of summit diplomacy. Also as a form of British exceptionalism causing Chamberlain to cast aside the constraints imposed by his half-brother Austen at Locarno, in favour of a policy which saw Great Britain having a particular national role to preserve world peace. Curiously, and rather in contradiction to his comments about the Polish Corridor (echoed in his way by Tomáš Masaryk) Austen Chamberlain himself spoke in March 1925 of how the United States was fixated by post-First World War monetary settlement, and thus Britain was "the one possible influence for peace and stabilisation. Without our help things will go from bad to worse." ${ }^{72}$ Therefore, as Professor Erik Goldstein has pointed out

\footnotetext{
68 DUFF COOPER, Alfred: Old Men Forget. London, Hart Davis 1955, p. 211.

69 ZEMAN, Z. - KLIMEK, A.: The Life of Edvard Beneš 1884-1948, p. 122.

70 LUKES, I.: Czechoslovakia Between Stalin and Hitler, pp. 91-113.

71 BÉDARIDA, François: La “gouvernante anglaise”. In: REMOND, René - BOURDIN, Janine (eds.): Edouard Daladier, chef de gouvernement. Paris, Plon 1975, pp. 228-240.

$72 D B F B, 1^{\text {st }}$ Series, Vol. 27, London, H.M.S.O. 1986, No. 256, Chamberlain to Howard (Washington), 18 March 1925.
} 
in a key essay, although the concept of "exceptionalism" is generally associated with American foreign policy, it "applies equally well to Britain in this period". ${ }^{73}$

Chamberlain's many critics have seen the whole démarche leading to $\mathrm{Mu}$ nich as a result of obstinate vanity and stubbornness, by a man who was effortlessly deceived by Hitler. "If at first you don't appease" ran the contemporary jingle, "fly, fly again". ${ }^{4}$

In fact, at both the political and diplomatic levels, British appeasement policy between 1937 and 1939 was about nuance. Vansittart has long had a reputation as the doughtiest of anti-appeasers as Permanent Under Secretary, and then as Chief Diplomatic Adviser at the Foreign Office. Yet, just as he supported the sellout Hoare-Laval Plan in 1935 to appease Benito Mussolini over Ethiopia, Vansittart's role over Czechoslovakia was not as heroic as is sometimes presented. ${ }^{75} \mathrm{His}$ hostility to Beneš has already been referred to but it went further than that so that in the crucial period between June and mid-July 1938 "the main instigator of [the] saturation bombardment of a friendly country" was Vansittart. ${ }^{76}$ Plainly he was manipulated into believing that the avuncular Henlein was a moderate, who was not taking orders from Berlin (Orme Sargent also believed this). One might, however, have expected that two high-ranking Foreign Office officials would not be duped by a mediocre ex-gym teacher. Conversely, the wiser line taken by Basil Newton about Henlein deserves some credit. He refused a request from Halifax and Sargent to open up a direct link between his legation and Henlein, against the stated wishes of President Beneš. Ultimately, the link remained in Vansittart's hands via his circle of unofficial informants. ${ }^{77}$

On the British side the key figure at the time of Munich has to be Chamberlain. He was able to dominate his Cabinet, with just one wobble involving Halifax, his most important supporter, whose crisis of conscience over the Godesberg terms was triggered by the unlikely personage of the new Permanent Under Secretary Sir Alexander Cadogan, normally a reliable supporter of Chamberlain's

${ }^{73}$ GOLDSTEIN, Erik: Neville Chamberlain, the British Official Mind and the Munich Crisis. In: LUKES, Igor - GOLDSTEIN, Erik (eds.): The Munich Crisis 1938: Prelude to World War Two. London, Frank Cass 1999, pp. 276-292, here p. 277.

${ }^{74}$ A fairly recent example of the genre can be found in McDONOUGH, Frank: The Origins of the Second World War: An International Perspective. London, Continuum 2011, pp. 168-186.

${ }^{75}$ A very recent example of Vansittartophilia can be found in BOUVERIE, Tim: Appeasing Hitler: Chamberlain, Churchill and the Road to War. London, The Bodley Head 2018, pp. 227-228 and 238, which fails to mention Vansittart's links with Henlein.

${ }^{76}$ VYŠNÝ, P.: The Runciman Mission to Czechoslovakia 1938, p. 105.

77 TNA, FO 371/21716, C3441/1941/18, Minutes by Sargent, 27 April 1938, and Halifax, 2 May 1938, also Sir William Strang (Head of the Central Department of the Foreign Office), 6 May 1938. See also: VYŠNÝ, P.: The Runciman Mission to Czechoslovakia 1938, p. 106. 
appeasement policy. He was outraged by the Godesberg terms and wrote in his diary that he "would rather be beat than dishonoured" ${ }^{78}$ It was only a blip though, although Chamberlain was shocked when Halifax told the Cabinet that he "did not think it right to put pressure on the Czechs". By the time Chamberlain flew to Munich on 29 September, however, Halifax (and Cadogan) were back in line. His towering figure was there to see Chamberlain off at Croydon Airport.

\section{British and Czech Attitudes Towards Munich}

The haunting image of Munich remains, and with it British guilt. Chamberlain and Daladier failed to secure proper Czech representation at the Conference and this was seen as a deliberate slight. Jan Masaryk called Munich "a unique bestiality" and that was the general Czechoslovak view. ${ }^{79}$ Newton's pre-conference bullying was combined with the image of Chamberlain, yawning insensitively as the Czech envoys Vojtěch Mastný, their Minister in Berlin, and Hubert Masařík, private secretary to the Foreign Minister Kamil Krofta, were told of their country's dismemberment by the Munich Agreement. ${ }^{80}$

It did not end there as the Czech historian Vít Smetana has pointed out in his path-breaking In the Shadow of Munich. The embittered Beneš was forced to resign after Munich and remained convinced in exile that the Foreign Office had a Munich complex, which withheld from the Czechs the recognition given to the Polish government-in-exile until 1941. According to Beneš, Britain owed more to Czechoslovakia than to any other country because of Munich. ${ }^{81}$

One remarkable feature of the Anglo-Czech debate about Munich in recent years has been that Czech attitudes seem to have changed more than the British ones. A. J. P. Taylor's controversial 1961 The Origins of the Second World War with its defence of appeasement, was finally translated into Slovak in $2005^{82}$ as was my own sympathetic Hitler and Appeasement: The British Attempt to Prevent

78 DILKS, David (ed.): The Diaries of Sir Alexander Cadogan 1938-1945, London, Cassell 1971, pp. 104-105, entries for 24 and 25 September 1938; NEVILLE, Peter: Sir Alexander Cadogan and Lord Halifax's "Damascus Road" Conversion over the Godesberg Terms 1938. In: Diplomacy and Statecraft, Vol. 11, No. 3 (November 2000), pp. 81-90.

79 The full quotation was "a unique bestiality in international relations". See ZEMAN, Z. - KLIMEK, A: The Life of Edvard Beneš 1884-1948, p. 117.

${ }^{80}$ In reality it is not surprising that a man of almost seventy years of age who had visited Germany three times in a fortnight should be tired.

81 SMETANA, Vít: In the Shadow of Munich: British Policy Towards Czechoslovakia from the Endorsement to the Renunciation of the Munich Agreement. Prague, Karolinum Press 2008, p. 298.

82 TAYLOR, A. J. P.: Príćiny druhej svetovej vojny. Bratislava, Perfekt 2005. 
the Second World War (2008). ${ }^{83}$ In that same year Smetana's book on Munich and its aftermath appeared in the Czech Republic, which showed a better understanding of the rationale behind appeasement. Thus, in describing the fears in Britain in the immediate period around the Munich Crisis Smetana could write: "War again! Just twenty years after the horrors of the Great War in which more than nine hundred thousand British soldiers had died, and one generation of the British upper class had been almost entirely exterminated." ${ }^{84}$ There was too a movement away from the depiction of Chamberlain as either a villain or a buffoon, with a more critical analysis of the behaviour of Beneš and his government.

The only book that Neville Chamberlain wrote was in memory of his beloved cousin Norman, who died in the trenches on the Western Front in 1917. The personal impact of this on Chamberlain has often been understated, and some recent analysis of appeasement in Britain has been very much in the old Churchillian tradition established by the first volume of his war memoirs in 1948, and now grown somewhat heavy. Nuance belongs to the minority, one of whom was the late Zara Steiner who, though critical of appeasement when appropriate, understood its origins and neuroses. Importantly also as far as France was concerned, she recognized that Munich represented "a means of escape from a war [Daladier] knew it was in no state to fight". ${ }^{85}$

Chamberlain returned from Munich in an atmosphere of hysterical jubilation (Daladier, who well knew what he had given away at Munich, was amazed by his hero's welcome in Paris). On his way to Buckingham Palace, where he was accorded the rare privilege of appearing on the balcony with George VI and his family, his car was mobbed "by people of every class, shouting themselves hoarse, leaping on the running board". ${ }^{86}$ In Prague by contrast there was desolation, and a feeling of betrayal. Beneš announced his resignation on 5 October, a week after Munich. Chamberlain had spoken of "Peace in our time", and whether he later regretted this is in a sense irrelevant. The remark reflected the aspirations of the British people, even though they were soon to be disillusioned (primitive polls after Munich showed a change of mood).

${ }^{83}$ NEVILLE, Peter: Hitler a appeasement: Britský pokus zabránit druhé světové válce. [Líbeznice], Víkend 2008.

${ }^{84}$ Ibid., p. 56. The change of nuance is also evident in Martin Kovár's foreword to NEVILLE, P.: Hitler a appeasement, pp. 5-6.

${ }^{85}$ STEINER, Zara: The Triumph of the Dark: European International History 1933-1939. Oxford, Oxford University Press 2011, p. 643.

${ }^{86}$ SELF, Robert (ed): The Neville Chamberlain Diary Letters, Vol. 4: The Downing Street Years, 1934-1940. Aldershot, Ashgate 2005, p. 351, Neville to Ida Chamberlain, 2 October 1938. 
It could hardly have been otherwise, as Smetana has pointed out. The wider question is whether it was ever reasonable for Czechoslovakia to expect British support in military or diplomatic terms at the time of Munich. Any British obligation was limited to those obtaining under the League of Nations Covenant. Britain, despite these, had not been willing to fight against Japanese aggression in Manchuria in 1931 and mainland China in 1937. It had been willing to apply only limited economic sanctions against Mussolini in 1935 over Ethiopia. The Spanish Civil War had only elicited a desire to remain out of the conflict (the heroic British members of the International Brigades excepted). No one had supported action over the Rhineland in 1936, even Churchill later conceded that there was no appetite for action, as did Labour leaders like Hugh Dalton. Nor had anyone, despite some bellicose rhetoric from Vansittart, wanted to send military assistance to Austria at the time of the Anschluss. ${ }^{87}$ Britain contented itself with a diplomatic protest.

The riposte to all this, crushing in its logic for many, focuses on the severity of Czechoslovakia's loss at Munich. Its defences down, and the loss of territory and hundreds of thousands of its Czech citizens, left the rump state dependent on a dubious Anglo-French guarantee which ultimately proved useless. By March 1939, the state of Czechoslovakia had disappeared from the map.

There was also an immense military loss at and after Munich. Four hundred and sixty-nine tanks were lost, and Milan Hauner has pointed out that "almost 350 of these were of the standard LT34 and LT35, superior in guns and armour to any of the available German Mark I and Mark II. (...) Three out of ten German panzer divisions incorporated them and every third tank which attacked France [in 1940], was Czech built." ${ }^{88}$ Hitler also claimed that Germany had acquired 43,876 machine guns, 501 anti-aircraft guns, 1589 aircraft, and much else. ${ }^{89}$ The wrecking of a fine, 30-division Czechoslovak army is often referred to in the literature, along with the loss of the Sudeten defences. As always though, when dealing with Munich and its problems major caveats need to be entered. It has long been known, for example, that the French had better quality tanks even when the Czech tanks are included. It was their misuse by Gamelin and his generals which proved crucial.

\footnotetext{
87 Vansittart's bravado was deflated by Cadogan, who asked him “Will you fight?" Vansittart replied "No," Cadogan's riposte was devastating: "To me it seems a cowardly thing to do to urge a small man to fight (...) if you won't help him." See DILKS, D. (ed.): The Diaries of Sir Alexander Cadogan 1938-1945, p. 63, entry for 16 March 1938.

${ }^{88}$ Milan Hauner is quoted by GRANT DUFF, S.: The Parting of Ways, p. 187.

89 Ibid., p. 187.
} 
Beneš, like Neville Chamberlain, was subjected to much abuse in his own country in the years after Munich for opting not to fight. In his memoir Munich Days, published in 1955 in London, ${ }^{90}$ Beneš argued that to fight without AngloFrench support would have been highly irresponsible, as such a war could not have been won. He even refuted the idea, presented by some, that if Czechoslovakia had fought, Britain and France would have been shamed into action. ${ }^{91}$

British policy at the time of Munich as before, rested on an assumption that peace was better than war, and that the Great War had shown that even where victory was achieved, the price was unacceptable. The generation of Stanley Baldwin and Neville Chamberlain had not fought in that war and believed this implicitly (though neither were pacifists). This did not mean that Chamberlain did not see after Munich that the peace obtained there could be a false dawn. Steiner, who can be fiercely critical, wrote that "he was far too intelligent and rational not to have considered the alternative reading of Hitler's mind". ${ }^{92}$

A. J. P. Taylor famously described Munich as "a triumph for all that was best and most enlightened in British life; a triumph for those who had preached equal justice between peoples". ${ }^{93}$

This controversial judgement has been interpreted by Hauner in two ways. Either as a defence of those who denounced the harshness and short-sightedness of Versailles (though Czechoslovakia lay outside that treaty's scope), and thus was a central tenet of appeasement. Or as a sarcastic attack on the British establishment at the time. This second interpretation would carry some weight if it had been presented by the Taylor of 1938. A young Labour Party activist and opponent of appeasement (it is worth noting that Labour had consistently voted against arms estimates in the House of Commons in the 1930s, which had been designed to strengthen Britain's defences when Baldwin and Chamberlain were in Downing Street) who had opposed Munich.

Taylor's Origins was published in 1961, by when he had also produced his favourite book The Troublemakers (1957), about the dissenting tradition involving men like Cobbett and H. N. Brailsford in British foreign policy. Taylor wrote

\footnotetext{
90 BENEŠ, Edvard: Mnichovské dny [The Munich Days]. Londýn, Ústav dr. Edvarda Beneše 1955.

${ }^{91}$ JACKSON, Julian: The Fall of France: The Nazi Invasion of France. Oxford, Oxford University Press 2003, pp. 13-14. Jackson points out that in 1940 the French had 2,900 tanks available, more than "those on the German side (including the Czech tanks)". They were also qualitatively "more than a match for the panzers". There is much literature going back to the 1970s on this. See TÁBORSKÝ, Edward: President Beneš and the Crises of 1938 and 1948. In: East Central Europe / L'Europe du Centre-Est, Vol. 5, No. 2 (1978), pp. 205-206.

92 STEINER, Z.: The Triumph of the Dark, p. 656.

93 TAYLOR, A. J. P.: The Origins of the Second World War. London, Penguin 1963, pp. 234-235. See also p. 26.
} 
of how these British dissenters "have always claimed that the Cause of Right (...) was also a better way of securing peace". It was no accident that Britain's prime minister at the time of Munich came from a non-conformist background. ${ }^{94}$

In 1938 Chamberlain thought he was protecting the rights of the Sudeten Germans by allowing their annexation by Germany, thus avoiding war (by an historic irony the Sudetens lost their right to self-determination in 1945 at the hands of Beneš and a liberated Czechoslovakia). This view was shared by other British leaders, who dined out on the evils of the Versailles system and how Sudeten Germans, Magyars and Poles had been deprived of their rights. Instead of applying a traditional balance of power methodology Baldwin, and especially Chamberlain, coated their fear of war with a veneer of righteousness. This was what Taylor referred to in his notorious 1961 judgement.

Hauner also gives us an interesting anecdote. Taylor had told him about a meeting he had with the restored President Beneš in 1946. As they looked out at the magnificent panorama provided from the President's office in the Hradčany Castle Beneš claimed that at Munich "I saved Prague and my people from destruction". ${ }^{95}$ Taylor had claimed in his book that Beneš was the true winner at Munich, as many more Poles died in the Second World War as a result of going to war in 1939, than did Czechs by staying out of a war in 1938. It was a view which the vast majority of Czech men and women would have rejected, then and (probably) now. They also saw Beneš humiliated a second time at the hands of Klement Gottwald's Communist Party in 1948, one of his accusers over Munich, and Jan Masaryk murdered, the assumption being that he was pushed out of the window of his flat in the Foreign Ministry building.

The Anglo-Saxon conscience continues to be troubled by Munich which remains a contentious subject, especially in the United States even though it did not participate in the Munich Agreement and where President Roosevelt signaled approval to Chamberlain in a famous two-word telegram "Good Man!". At the popular level in Britain the view of it as an unprincipled sellout still holds sway.

Britain was not well served by its diplomats in Prague between 1919 and 1939. Even Sir George Clerk, the friend of Tomáš Masaryk lapsed into racial stereotypes on occasion. The situation improved after 1945, when the British diplomats (though persecuted by the Czech communist regime) showed more sensitivity. The outstanding example was Sir Cecil Parrott (1960-1966), an ambassador who familiarized himself and his countrymen and women with Jaroslav Hašek's The Good Soldier Švejk and founded the Department of Slavonic Studies at the

\footnotetext{
94 TAYLOR, A. J. P.: The Troublemakers. London, Hamish Hamilton 1957, pp. 296-297.

95 HAUNER, M.: The Sudeten Crisis of 1938, p. 370.
} 
University of Lancaster. Parrott also translated Czech plays and literature into English. ${ }^{96}$ A far cry from the days of Sir Joseph Addison.

A sign of change in Czechoslovakia came with the recognition that right might not lie on only one side. The Republic was sundered by the so called "velvet divorce" of 1993 when Slovakia (rent apart from the Republic between 1939 and 1944), finally broke away. The Czech Republic had a globally respected President in the playwright Václav Havel, who recognized the brutality with which historic revenge was meted out to the Sudeten Germans in 1945.

In reviewing the Munich experience Havel noted in a 1990 speech that in 1938 “it was our own leaders' fear of standing up to a numerically superior force" that contributed to the tragedy of Munich. Britain and France were guilty of an "infinite short-sightedness" in Havel's view but the Beneš government might have been guilty of a "belittling attitude (...) toward the rights of its national minorities". ${ }^{97}$ This, Havel recognized, could have contributed to the attitudes towards Sudeten Germans.

This was generous. Havel went further in condemning a spirit of collective animosity so that "we drove them out of the country and punished them with the kind of retribution that went beyond the rule of law" ${ }^{98}$ Beneš had in fact secured Allied approval for this retribution. British guilt over Munich played its part, Beneš went on believing that he had won the right of revenge. ${ }^{99}$ No doubt he deemed himself unfortunate to have such unsympathetic British ministers in Addison and Newton. The Poles, who were to suffer an even worse fate, at least had empathetic men in the post in Howard Kennard and Clifford Norton. ${ }^{100}$

The central feature in Anglo-Czech relations between 1938 and 1945 was Beneš's conviction that Great Britain had a debt of honour to pay, because of the "unique bestiality" of Munich. He also blamed the British for their tardiness

\footnotetext{
96 WITTLICH, F.: 100 Years of the British Embassy in Prague, p. 40.

97 HAVEL, Václav: Toward a Civil Society: Selected Speeches and Writings 1990-1994. Prague, Nakladatelství Lidové noviny 1994, p. 46. The quotation is from the speech of welcome to President of FRG Richard von Weizsäcker in Prague, March 15, 1990 (pp. 46-55). Translated from Czech by Paul R. Wilson.

98 Ibid., p. 48.

99 SMETANA, V.: In the Shadow of Munich, pp. 305-306.

100 Sir Howard Kennard (1934-1939) and Sir Clifford Norton (1937-1939) sympathized with the Polish plight in 1939. Norton went hunting with Polish minister of Foreign Affairs Józef Beck on occasion. See GILBERT, Martin - GOTT, Richard: The Appeasers. London, Macmillan 1963, pp. 252-254. In his memoirs Robert Vansittart confessed to "some liking for Beck". See VANSITTART, Robert: The Mist Procession. London, Hutchinson 1958, p. 252.
} 
in repudiating Munich and recognizing Czechoslovakia's 1937 borders. This only happened in March 1945. ${ }^{101}$

Munich has been about absolutes. Czech anger and bitterness were encapsulated in František Halas' poem which tugs at the heartstrings:

Zvoní zvoní zrady zvon zrady zvon

Čí ruce ho rozhoupaly

Francie sladká hrdý Albion

a my jsme je milovali ${ }^{102}$
(The bell of treason is tolling

Whose hand made it swing?

Sweet France Proud Albion

And we loved them)

"Proud Albion" carried its guilt for decades. As a foreign power like France, it could not though be guilty of the treason the poet referred to. ${ }^{103}$

\section{Abstract}

The focus of the article is the poor quality of British diplomats in Prague between 1919 and 1939. The article shows this to be a result of a cult of ignorance in the British Diplomatic Service. The Sudetenland German aristocracy was much preferred to Czechs and Slovaks, something which was clearly evident during Lord Runciman's mediation process in 1938. The inability of diplomats like Basil Newton to profit from periods of service in Berlin, where the true nature of Nazism should have been clear, was evident. The article does also show however, that the Czechoslovak government did not always act to its best advantage. Remarks by President Tomáš Masaryk in the 1920s and 1930s seemed to show an unwillingness to assist Poland if the status of the Polish Corridor was threatened. This played into the hands of British statesmen such as Sir Austen Chamberlain, who wished to avoid any commitment to the post-World War I settlement in Central and Eastern Europe. He limited territorial guarantees to Western Europe at Locarno in 1925 and, as the article points out, the growing rift between London and Prague was demonstrated by the British refusal to send a delegation for Masaryk's eightieth birthday celebration. The British animosity towards Masaryk's successor, President Eduard Beneš, is

\footnotetext{
101 SMETANA, V.: In the Shadow of Munich, pp. 304-306.

${ }^{102}$ HALAS, František: Zpěv úzkosti [Song of Anxiety]. In: IDEM: Torso naděje [Torso of Hope]. Praha, Fr. Borový 1939, p. 21 [first published in 1938].

${ }^{103}$ A recent powerful attack on the Czech tendency to feel victimized can be found in SMETANA, Vít: Ten Propositions about Munich: The Fateful Event of Czech and European History - without Legends and National Stereotypes. In: Czech Journal of Contemporary History, Vol. 7, No. 1 (2019), pp. 5-14. A much more sympathetic biography of Neville Chamberlain has been written by Andrew Crozier and will be published by Bloomsbury, London in 2022.
} 
a theme of the article. Munich is therefore analysed in the context of a lengthy period between 1919 and 1938, when British statesmen and diplomats showed overt sympathy for minority German, Magyar and Polish groupings in the Czechoslovak Republic. Beneš and his government were also regarded as too pro-French, and too pro-Soviet. A major sub-theme is the extent to which Britain could or should have given military assistance to Czechoslovakia in September 1938. Neville Chamberlain appears as a prime minister who understood military realities, having received advice from his generals which was pessimistic about Czech chances of survival. Finally, the article refutes the suggestion by P. E. Caquet that Britain as a foreign power could be guilty of "treason" in 1938.

Keywords:

Anglo-Czech relations; Czechoslovakia; Great Britain; British diplomats in Prague 1919-1939; Munich Agreement 1938; appeasement 